\title{
Inventarisasi, kunci identifikasi, pemetaan, dan rekomendasi pengelolaan jenis-jenis bambu di ecology park, pusat konservasi tumbuhan, kebun raya-LIPI, Kabupaten Bogor, Jawa Barat
}

\author{
I Putu Gede P. Damayanto1,*, Sri Mulyani², Baiq Farhatul Wahidah²
}

1. Herbarium Bogoriense (BO), Lembaga IImu Pengetahuan Indonesia (LIPI), Jawa Barat, Indonesia, 16911

2. Prodi Biologi, Fakultas Sains dan Teknologi, Universitas Islam Negeri Walisongo, Jawa Tengah, Indonesia, 50185

^E-mail: parlida.damayanto.tab@gmail.com

\begin{abstract}
Inventory, identification key, mapping, and management recommendation of bamboo species in the ecology park, center for plant conservation, botanic gardens-LIPI, Bogor Regency, West Java. This study aimed to make an inventory of bamboo species to provide an identification key, a distribution map of those bamboos, as well as, a recommendation on bamboo management in the Ecology Park. The study was conducted in January-February 2019 using the exploration method, located in the Ecology Park, Center for Plant Conservation, Botanic Gardens, Campus of Cibinong Science Center-Botanic Gardens (CSC-BG), LIPI, Cibinong, Bogor, West Java. The bamboo herbarium specimens were made to determine the bamboo species found in the Ecology Park. The bamboo specimens were processed and deposited in the Herbarium Bogoriense (BO). The morphology characters of bamboo were described and to be used to determine the species and also to provide an identification key. The distribution map of bamboo in the Ecology Park created and it was overlapped with the existing map of the Ecology Park area. The bamboo management recommendation was made based on the data of bamboo inventory and mapping. The results showed that there are three species of bamboo from 40 clumps found in the Ecology Park, namely Bambusa vulgaris (bambu ampel), Gigantochloa apus (bambu tali), and G. pseudoarundinacea (bambu andong). These bamboos were alleged spontaneous collection and mostly distributed near the lake and along the road. An identification key to the species and a distribution map of bamboo species in the Ecology Park were presented. These bamboos play an important role in the Ecology Park to maintain water availability and to help to prevent a landslide. It is recommended that bamboo clumps in Ecology Park need to be tidied by making a fence and thinning of bamboo clumps needs to be done at least every 2 years. The management staff need to enrich the bamboo species in the Ecology Park, particularly ornamental and endemic bamboo of Indonesia, such as Schizostachyum brachycladum (bambu gading) and Dinochloa scandens (bambu cangkoreh), planted in accordance with the bioregion where the species come from.
\end{abstract}

Keywords: bamboo, distribution map, ecology park, identification key, inventory, management recommendation

\section{Pendahuluan}

Kehadiran tanaman bambu dalam sebuah taman dapat menjadi daya tarik tersendiri untuk taman itu sendiri. Perawakan bambu yang merumpun dan berbeda dengan pohon secara umum memberikan variasi bentuk tegakan pada elemen lunak taman. Selain sebagai variasi elemen lunak pada taman, tanaman bambu juga dapat menjadi penyokong aspek ekologis pada taman itu sendiri. Seperti diketahui, tanaman bambu dilaporkan bermanfaat bagi lingkungan untuk menjaga tanah dari erosi, berperan dalam konservasi air, menyerap gas rumah kaca, dan melepaskan oksigen ke atmosfer (Wong, 2004; Wang, dkk., 2013; Huang, dkk., 2014). Selain itu, pengelola taman juga dapat memanfaatkan tanaman bambu secara langsung sebagai material utama dalam elemen keras taman seperti dijadikan sebagai pagar, bahan dasar pembuatan pondok peristirahatan, material pembuatan jembatan, dan lain sebagainya. Dengan demikian, pengelolaan taman menjadi lebih murah, efisien, dan memunculkan kesan alami.

Pemanfaatan tanaman bambu sebagai elemen dalam taman dapat dijumpai pada beberapa taman di Indonesia. Taman Monumen 45 Kota Pekalongan misalnya, tanaman bambu kuning ditanam sebagai elemen 
lunak taman yang dianggap sebagai simbol perjuangan (Rochim \& Syahbana, 2013). Sementara itu, Taman Eden 100 di Sumatera Utara juga dilaporkan menggunakan tanaman bambu sebagai salah satu elemen lunak tamannya (Damayanto, 2018a). Tanaman bambu juga terlihat digunakan sebagai elemen taman di pusat perbelanjaan di kota-kota besar di Indonesia. Di sisi lain, pemanfaatan perawakan tanaman bambu sebagai elemen keras berupa tugu bambu runcing dapat dijumpai pada Taman Digulis di Kota Pontianak (Liberani, 2017) dan Taman Monumen Bambu Runcing di Kota Surabaya (Tauhid, 2018).

Di wilayah Kabupaten dan Kota Bogor, Jawa Barat, tanaman bambu dapat dijumpai pada taman perkantoran, taman di area pabrik, dan ruang terbuka hijau (RTH). Taman di perkantoran, misalnya kantorkantor pemerintah daerah, biasanya ditanam jenis-jenis bambu ornamental seperti bambu gading [Schizostachyum brachycladum (Kurz ex Munro) Kurz]. Wilayah pabrik biasanya ditanam jenis bambu yang mampu meredam suara dan debu seperti bambu payung (Thyrsostachys siamensis Gamble). Bambu payung tersebut ditanam berjejer rapat sepanjang pagar pembatas pabrik sehingga polusi udara dan suara yang berasal dari dalam dan luar pabrik dapat dikurangi. Sementara itu, RTH di wilayah Kabupaten dan Kota Bogor biasanya memiliki koleksi tanaman bambu dari jenis-jenis asli daerah tersebut, sehingga jenis-jenis bambunya lebih beragam dan umumnya bukan jenis ornamental.

Salah satu RTH di wilayah Cibinong, Kabupaten Bogor, Jawa Barat adalah kampus Cibinong Science Center-Botanic Gardens (CSC-BG), Lembaga IImu Pengetahuan Indonesia (LIPI). Kampus CSC-BG memiliki konsep RTH yang terintegrasi dengan pusat-pusat penelitian LIPI di dalamnya dan direncanakan sebagai kompleks penelitian sejak 1964 (Imron, dkk., 2016). Di dalam kampus CSC-BG terdapat suatu area khusus yang diperuntukan sebagai taman wisata sekaligus area konservasi eksitu. Kawasan tersebut dikenal dengan nama Ecology Park (biasanya disingkat menjadi Ecopark). Ecology Park merupakan suatu ekosistem lahan basah yang dirintis pada tahun 2000 (Astuti \& Kurniati, 2010) dan mulai tahun 2002 dibangun sebagai kawasan konservasi eksitu (Imron, dkk., 2016). Ecology Park merupakan "perluasan" dari Kebun Raya Bogor (Nafar, 2016) dan cikal bakal Kebun Raya Cibinong di kemudian hari (Imron, dkk., 2016).

Sebagai RTH sekaligus area konservasi eksitu, Ecology Park tetap mempertahankan semua tumbuhan yang sudah ada sebelum kawasan ini dibangun, selain juga mendatangkan beberapa jenis tumbuhan, terutama pohon, untuk ditanam di kawasan ini. Sementara itu, sebagai kawasan penelitian, berbagai kegiatan penelitian di Ecology Park juga telah banyak dilakukan, antara lain penelitian tentang variasi serapan $\mathrm{CO}_{2}$ jenis-jenis pohon terkait potensi mitigasi gas rumah kaca (Hidayati, dkk., 2013), studi taksonomi jenis-jenis Diospyros (Putri \& Chikmawati, 2015), desain ekologis taman koleksi pakis berbasis sistem klasifikasi bioregion (Nafar, 2016; Nafar \& Gunawan, 2017), identifikasi kondisi kesehatan pohon peneduh (Noviady \& Rivai, 2015), keanekaragaman lumut kerak (Boerdeaux, 2015), keragaman dan kelimpahan jenis kodok (Kurniati, 2010; Astuti \& Kurniati, 2010), pola distribusi dan dinamika komunitas burung (Widodo \& Sulystiadi, 2016), serta input hara dari nekromasa (Kintamani, dkk., 2017). Terkini, daftar jenis tumbuhan di Ecology Park juga telah disusun oleh Ariati, dkk. (2018). Sayangnya, belum ada penelitian tentang bambu di kawasan Ecology Park. Bahkan daftar terkini jenis-jenis tumbuhan di Ecology Park oleh Ariati, dkk. (2018) tidak mencantumkan daftar jenis bambu di dalamnya. Padahal terlihat ada beberapa rumpun bambu yang tumbuh di Ecology Park dan keberadaan tanaman bambu tersebut bisa jadi sengaja ditanam atau memang sudah ada (koleksi spontan) dari sebelum Ecology Park ini dibangun.

Perlu dilakukan penelitian tentang keanekaragaman bambu di Ecology Park, sekaligus mengetahui perkembangan terkini terkait koleksi tanaman bambu dan perannya dalam ekosistem Ecology Park. Sebagai tambahan, saran-saran strategis juga perlu diberikan kepada pihak pengelola Ecology Park terkait perencanaan zona koleksi tanaman bambu sehingga arahan penambahan jenis dan pendistribusiannya dapat terencana dengan lebih baik. Hasil penelitian tersebut dapat menjadi tambahan data bagi pihak pengelola dalam menentukan strategi pengelolaan kawasan Ecology Park di masa depan dan melengkapi daftar jenisjenis tumbuhan Ecology Park yang telah disusun oleh Ariati, dkk. (2018).

Untuk itu, telah dilakukan penelitian yang bertujuan menyediakan informasi keanekaragaman jenisjenis tanaman bambu dan perannya dalam ekosistem melalui inventarisasi bambu di Ecology Park sekaligus menyediakan kunci identifikasi dan peta distribusi jenis-jenis bambu bagi pihak pengelola Ecology Park. Selain itu, dari hasil inventarisasi dan pemetaan jenis-jenis bambu di Ecology Park tersebut, juga telah disusun rekomendasi atau saran strategis terkait perencanaan zona koleksi tanaman bambu sehingga penambahan jenis dan pendistribusian tanaman bambu di Ecology Park diharapkan dapat lebih terencana. Sementara itu, kunci identifikasi jenis bambu diharapkan dapat membantu pengelola kawasan Ecology Park dalam mendata semua koleksi bambu yang mereka punya karena dalam penelitian ini tidak dilakukan pemberian label nama pada setiap rumpun yang dijumpai. Dengan demikian, pada akhirnya perencanaan pembentukan Kebun Raya Cibinong yang menyediakan data ilmiah tumbuhan di masa depan dapat terwujud. 


\section{Metode}

Penelitian ini dilaksanakan pada Januari sampai dengan Februari 2019. Pengumpulan material bambu dilakukan di Ecology Park, Pusat Konservasi Tumbuhan, Kebun Raya-LIPI. Sementara itu, pemrosesan spesimen bambu dilaksanakan di Herbarium Bogoriense (BO), Pusat Penelitian Biologi-LIPI. Pengumpulan material bambu dilakukan menggunakan metode jelajah dari Rugayah, dkk. (2004) yaitu menjelajahi setiap sudut Ecology Park dan mengoleksi contoh material bambu yang dijumpai. Metode jelajah yang digunakan adalah metode sensus, yaitu menghitung semua rumpun bambu yang dijumpai. Namun demikian, tidak semua bambu dikoleksi sebagai spesimen herbarium terutama untuk rumpun bambu yang saling berdekatan dan memiliki jenis yang sama. Pengambilan contoh material bambu hanya dilakukan pada salah satu rumpun pada sekelompok rumpun bambu yang tumbuh berdekatan. Namun, jika dijumpai jenis yang berbeda dalam rumpun yang berdekatan tersebut, maka pengambilan contoh material bambu dilakukan pada semua jenis yang berbeda tersebut.

Material bambu dikoleksi mengikuti metode dari McClure (1945). Material bambu diberi nomor koleksi dan nama pengumpul serta mencatat informasi penunjang seperti lokasi, titik koordinat, tanggal koleksi, kegunaan (bila ada) dan karakter morfologi yang akan hilang jika material dikeringkan (misalnya warna rebung dan buluh). Material bambu dimasukkan dalam lipatan koran dan dibasahi dengan alkohol $70 \%$. Material tersebut dibawa ke BO untuk pemrosesan dan identifikasi lebih lanjut. Pemrosesan material bambu menjadi spesimen herbarium mengikuti metode Djarwaningsih, dkk. (2002).

Spesimen bambu diidentifikasi menggunakan acuan spesimen bambu di BO dan beberapa literatur seperti Dransfield \& Widjaja (1995), Widjaja (1987; 1997; 2001a; 2001b), Widjaja, dkk. (2005), dan Damayanto \& Widjaja (2016; 2017). Setiap nama jenis dari hasil identifikasi tersebut kemudian divalidasi menggunakan acuan dari Vorontsova, dkk. (2016). Data berupa deskripsi morfologi setiap jenis bambu dijabarkan secara deskriptif. Kunci identifikasi tingkat jenis disusun berdasarkan deskripsi morfologi setiap jenis bambu. Foto setiap karakter morfologi bambu yang digunakan dalam kunci identifikasi juga dicantumkan. Sementara itu, peta distribusi bambu di Ecology Park dibuat dan ditumpangsusunkan dengan peta kawasan Ecology Park yang telah tersedia. Dari semua data yang ada, rekomendasi strategis terkait perencanaan zona koleksi tanaman bambu di Ecology Park disusun.

\section{Hasil dan Pembahasan}

\subsection{Hasil Penelitian}

Hasil inventarisasi bambu diperoleh bahwa terdapat tiga jenis bambu dari 40 rumpun yang tumbuh di Ecology Park (Tabel 1). Rumpun terbanyak dijumpai pada jenis Bambusa vulgaris dan yang paling sedikit adalah jenis Gigantochloa pseudoarundinacea. Sementara itu, semua jenis bambu yang ada di Ecology Park sudah dewasa dan dalam kondisi tidak berbunga (steril).

Tabel 1. Keanekaragaman Jenis Bambu di Ecology Park

\begin{tabular}{cllcl}
\hline No. & Nama Latin & Nama Indonesia & Jumlah Rumpun & Kondisi \\
\hline 1. & Bambusa vulgaris Schard. ex Wendl. & Bambu ampel & 32 & Dewasa, steril \\
2. & Gigantochloa apus (Schult.f.) Kurz & Bambu tali & 6 & Dewasa, steril \\
3. & $\begin{array}{l}\text { Gigantochloa pseudoarundinacea } \\
\text { (Steud.) Widjaja }\end{array}$ & Bambu andong & 2 & Dewasa, steril \\
\hline
\end{tabular}

\subsection{Pembahasan}

\subsubsection{Gambaran Singkat Ecology Park}

Ecology Park atau disingkat menjadi Ecopark secara administrasi berada di wilayah Kampus Cibinong Science Center - Botanic Gardens (CSC-BG), Lembaga IImu Pengetahuan Indonesia (LIPI). Kampus CSCBG sendiri memiliki luas sekitar 189 ha yang berlokasi di Jl. Raya Jakarta-Bogor, km 46, Cibinong, Kabupaten Bogor, Jawa Barat. Kampus CSC-BG memiliki konsep ruang terbuka hijau yang terintegrasi dengan pusatpusat penelitian di dalamnya dan direncanakan sebagai kompleks penelitian sejak 1964 (Imron, dkk., 2016).

Ecology Park hanya berjarak sekitar $500 \mathrm{~m}$ dari pintu gerbang Komplek Pemerintah Daerah Kabupaten Bogor (Jannah, 2017) atau $40 \mathrm{~km}$ di sebelah selatan Jakarta (Ariati, dkk., 2018). Secara geografis, Ecology Park terletak di ketinggian $165 \mathrm{~m}$ dpl (Kurniati, 2010) pada koordinat 6²9'34.7"LS dan 106 $51^{\prime} 09.5^{\prime \prime B T}$. Ecology Park memiliki luas sekitar 34 ha (Noviady \& Rifai, 2015; Imron, dkk., 2016; Madani, 2017; Sufa, 2017; Ariati, dkk., 2018). Awalnya, berdasarkan rencana induk (masterplan) 2003, Ecology Park direncanakan seluas 7,5 ha, namun sejak 2005 telah diperluas menjadi 32 ha (Ariati, dkk., 2018). Ecology Park memiliki danau buatan yang menampung limpahan air dari 23 titik mata air alami (Imron, dkk., 2016). Danau buatan ini dikenal oleh masyarakat sekitar sebagai Danau Dora (Nafar, 2016; Jannah, 2017), padahal danau ini secara resmi bernama Danau Cibuntu. Keliling dari danau tersebut sekitar $800 \mathrm{~m}$ dengan kedalaman air rata-rata $50 \mathrm{~cm}$ 
(Kurniati, 2010). Ecology Park memiliki suhu harian tertinggi sebesar $29^{\circ} \mathrm{C}$, kelembaban relatif udara harian terendah sebesar 74,8\%, dan intensitas cahaya 557,88 Lux (Boerdeaux, 2015).

Ecology Park merupakan suatu ekosistem lahan basah yang dirintis pada tahun 2000 (Astuti \& Kurniati, 2010). Mulai tahun 2002, Ecology Park dibangun sebagai kawasan konservasi eksitu (Imron, dkk., 2016) dan dibagi ke dalam beberapa bioregion. Bioregion merupakan pembagian zona kawasan yang mewakili setiap kawasan hutan di Indonesia. Hingga saat ini, Ecology Park terbagi dalam tujuh bioregion yaitu Sumatera, JawaBali, Nusa Tenggara, Kalimantan, Sulawesi, Maluku, dan Papua/Irian Jaya (Imron, dkk., 2016; Nafar, 2016, Madani, 2017; Sufa, 2017; Ariati, dkk., 2018). Ecology Park merupakan perluasan dari Kebun Raya Bogor (Nafar, 2016). Kebun Raya Bogor seluas 87 ha tidak dapat lagi diperluas, sementara kegiatan eksplorasi dan pengumpulan koleksi hidup tumbuhan terus berlangsung (Sufa, 2017). Perlu dibangun cabang kebun raya lain yaitu Ecology Park, yang dekat dengan Kebun Raya Bogor untuk mengakomodasi hasil pengumpulan spesimen hidup tumbuhan. Ecology Park merupakan cikal bakal Kebun Raya Cibinong (Imron, dkk., 2016).

Koleksi tumbuhan yang ada di Ecology Park dilaporkan lebih dari 10.000 pohon yang ditanam sejak 2002 (Imron, dkk., 2016; Madani, 2017). Secara rinci, koleksi tumbuhan di Ecology Park terdiri dari 7.577 spesimen yang tergolong ke dalam 105 suku, 346 marga, dan 901 jenis (Noviady \& Rifai, 2015). Namun, data terkini dan secara resmi dilaporkan oleh pihak pengelola Ecology Park yaitu terdapat 6.105 spesimen yang tergolong ke dalam 86 suku, 328 marga, dan 733 jenis (Ariati, dkk., 2018). Tahun 2017 dilaksanakan penanaman sebanyak 250 pohon di Ecology Park dengan jenis pohon yang ditanam diantaranya adalah kenari, nyatoh, kayu kolaka, kayu ular, dan rangas putih (Madani, 2017). Beberapa penelitian di Ecology Park telah dilakukan seperti variasi serapan $\mathrm{CO}_{2}$ jenis-jenis pohon terkait potensi mitigasi gas rumah kaca (Hidayati, dkk., 2013), studi taksonomi jenis-jenis Diospyros (Putri \& Chikmawati, 2015), desain ekologis taman koleksi pakis berbasis sistem klasifikasi bioregion (Nafar, 2016; Nafar \& Gunawan, 2017), identifikasi kondisi kesehatan pohon peneduh (Noviady \& Rivai, 2015), keanekaragaman lumut kerak (Boerdeaux, 2015), keragaman dan kelimpahan jenis kodok (Kurniati, 2010; Astuti \& Kurniati, 2010), pola distribusi dan dinamika komunitas burung (Widodo \& Sulystiadi, 2016). ), serta input hara dari nekromasa (Kintamani, dkk., 2017). Terakhir, jenis-jenis tumbuhan di Ecology Park juga telah didata dan disusun daftarnya oleh Ariati, dkk. (2018). 3.2.2. Keanekaragaman Jenis Bambu di Ecology Park

Terdapat tiga jenis dari dua marga bambu yang tumbuh di Ecology Park, yaitu B. vulgaris (bambu ampel), G. apus (bambu tali), dan G. pseudoarundinacea (bambu andong). Semua jenis bambu tersebut sangat umum dijumpai di wilayah Jawa (lihat Widjaja, 2001a). Secara keseluruhan, terdapat 40 rumpun bambu di Ecology Park. Walapun jumlah rumpunnya tergolong tinggi, namun keanekaragaman jenisnya masih tergolong rendah. Dari ketiga jenis bambu yang ada di Ecology Park, $B$. vulgaris memiliki jumlah rumpun yang paling banyak (32 atau 80\%) dibandingkan jenis lainnya. B. vulgaris sepertinya merupakan koleksi spontan atau asli (memang sudah ada) di Ecology Park sehingga jumlah rumpunya melimpah. Hal ini terlihat dari rimpang setiap rumpun bambu cukup banyak dan telah tumbuh meninggi dari permukaan tanah, serta rumpun yang memiliki jumlah buluh yang banyak dan buluh telah tumbuh mencapai ketinggian maksimal yang menandakan rumpun tersebut telah dewasa dan mungkin berumur sekitar 5-10 tahun bahkan bisa lebih tua. Hal ini juga didukung oleh banyaknya jenis $B$. vulgaris yang ditemukan di sekitar area CSC-BG. Sementara itu, G. apus dan G. pseudoarundinacea juga diduga merupakan koleksi spontan yang telah ada jauh sebelum kawasan Ecology Park dibangun sebab rumpun yang ada sudah cukup tua yang serupa dengan karakter rumpun $B$. vulgaris. Hal ini didukung oleh pernyataan Sumadi (2019, komunikasi pribadi), salah satu staf pengelola Ecology Park, yang menyatakan bahwa belum pernah ada penanam bambu di Ecology Park, sehingga rumpun bambu yang ada merupakan koleksi spontan.

Pada penelitian sebelumnya, pernah dilaporkan keberadaan jenis-jenis bambu di Ecology Park, namun tidak secara tegas melaporkan jenisnya. Nafar (2016) misalnya, pernah melaporkan adanya bambu "liar" di Ecology Park, namun hanya melaporkannya sebagai Bambusa sp. Sementara itu, Nafar \& Gunawan (2017) juga melaporkan adanya rumpun bambu "liar" di Ecology Park, namun tanpa penjelasan lebih detail tentang jenisnya. Sesungguhnya, daftar terkini jenis-jenis tumbuhan di Ecology Park telah dikeluarkan secara resmi oleh pihak pengelola Ecology Park (lihat Ariati, dkk., 2018). Sayangnya, Ariati, dkk. (2018) tidak melaporkan keberadaan jenis-jenis bambu di Ecology Park. Hal tersebut juga berlaku tidak hanya untuk bambu, melainkan juga untuk semua jenis suku Poaceae (rerumputan). Menurut Ariati (2019, komunikasi pribadi) menyatakan bahwa tumbuhan yang dimasukkan dalam daftar jenis tumbuhan di Ecology Park pada Ariati, dkk. (2018) adalah hanya untuk tumbuhan yang berstatus sebagai "koleksi" dan memiliki asal usul yang jelas sehingga bisa ditentukan lokasi penanamanya pada bioregionnya. Jenis-jenis tumbuhan tersebut merupakan koleksi yang diintroduksi ke Ecology Park dari beberapa daerah di Indonesia atau pada kasus tertentu koleksi tumbuhan dapat merupakan koleksi spontan di Ecology Park.

Semua koleksi bambu di Ecology Park sedang tidak dalam masa perbungaan. Bunga pada sebagain besar jenis bambu dilaporkan jarang dijumpai (Widjaja, 2001a; Ervianti, 2015), walapun beberapa jenis seperti 
S. brachycladum selalu berbunga sepanjang tahun. Jenis $B$. vulgaris dilaporkan berbunga kira-kira setiap 150 tahun (Janzen, 1976). Sementara itu, sebagian besar bambu yang ada di Ecology Park, terutama jenis $B$. vulgaris, ditemukan tumbuh di sepanjang tepi danau dan sungai. Widjaja (2001a) menyatakan bahawa $B$. vulgaris mampu tumbuh pada tempat yang tergenang air selama beberapa bulan. Dengan demikian, $B$. vulgaris tidak akan mati jika air danau atau sungai meluap dan menggenangi tanaman bambu tersebut, terutama ketika musim hujan. Deskripsi dan foto setiap jenis bambu di Ecology Park disajikan sebagai berikut. 1. Bambusa vulgaris (Gambar 1)

Rebung berwarna hijau atau kuning, tertutup miang berwarna coklat hingga hitam. Rumpun agak rapat; buluh tegak, berwarna hijau mengkilap atau kuning dengan garis-garis hijau, agak berbiku-biku, tinggi 7-16 $\mathrm{m}$, diameter $5-9 \mathrm{~cm}$, ruas $23-30 \mathrm{~cm}$. Percabangan dekat dengan tanah, terdiri dari satu cabang yang lebih besar dikelilingi oleh beberapa cabang yang berukuran lebih kecil. Pelepah buluh mencapai 12,5-37 × 18,5$53 \mathrm{~cm}$, mudah luruh, diselimuti miang berwarna coklat tua; kuping membulat dengan ujung melengkung ke luar, tinggi 1-1,5 mm, dengan bulu kejur 5-7 mm panjangnya; ligula menggerigi, tinggi 1-3 mm, bulu kejur 1 $\mathrm{mm}$ panjangnya; daun pelepah buluh tegak, menyegitiga dengan pangkal melebar, 9,4-12,5 $\times 2,5-9 \mathrm{~cm}$. Daun memita, $17,8-27 \times 1-3,4 \mathrm{~cm}$, permukaan bagian bawah daun tidak terdapat bulu balig; kuping kecil berukuran 1-2 $\mathrm{mm}$ dengan bulu kejur 1-2 $\mathrm{mm}$ panjangnya; ligula rata dengan tinggi 1-2 $\mathrm{mm}$.

Terdapat tiga varietas B. vulgaris (Widjaja, 2001a), yaitu B. vulgaris var. vulgaris (buluh berwarna hijau), B. vulgaris var. striata (buluh berwarna kuning dengan garis-garis hijau), dan B. vulgaris var. wamin (buluh berwarna hijau dan menggembung pada ruasnya). Berdasarkan hasil inventarisasi, hanya terdapat dua varietas $B$. vulgaris di Ecology Park, yaitu B. vulgaris var. vulgaris (Gambar $1 A$ ) dan B. vulgaris var. striata (Gambar 1B).
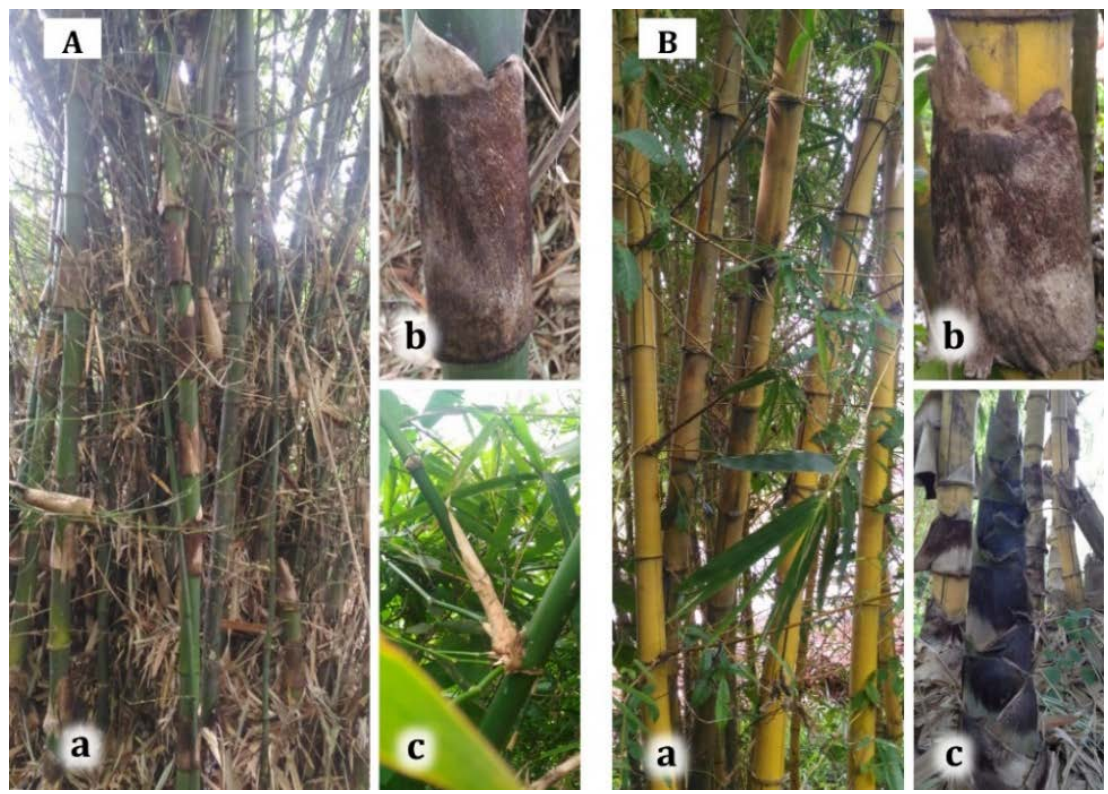

Gambar 1. Bambusa vulgaris var. vulgaris (A) dan B. vulgaris var. striata (B). Keterangan A: perawakan (a); pelepah buluh (b); percabangan (c). Keterangan B: perawakan (a); pelepah buluh (b); rebung (c)

(Foto: I Putu Gede P. Damayanto)

\section{Gigantochloa apus (Gambar 2)}

Rebung berwarna hijau, tertutup miang coklat dan hitam. Rumpun agak rapat; buluh tegak dengan ujung melengkung, berwarna hijau, tinggi 8-13 m, diameter 6-8 cm, dan ruas $30-35 \mathrm{~cm}$. Percabangan $1,5 \mathrm{~m}$ dari permukaan tanah, terdiri dari satu cabang yang lebih besar dikelilingi oleh beberapa cabang yang berukuran lebih kecil. Pelepah buluh mencapai $29,3 \times 37,3 \mathrm{~cm}$, tidak mudah luruh, diselimuti miang berwarna coklat; kuping berbentuk bingkai, 1-2 $\mathrm{mm}$, dengan bulu kejur 5-6 mm panjangnya; ligula menggerigi, tinggi 1-3 mm, gundul; daun pelepah buluh tegak saat muda dan terkeluk balik saat tua, menyegitiga dengan pangkal sempit, 7,3 × 4,5 cm. Daun memita, 28,5-36 × 4,2-5 cm, permukaan bagian bawah daun terdapat bulu balig; kuping pelepah daun kecil berukuran $1 \mathrm{~mm}$, gundul; ligula rata dengan tinggi 1-3 mm, gundul. 


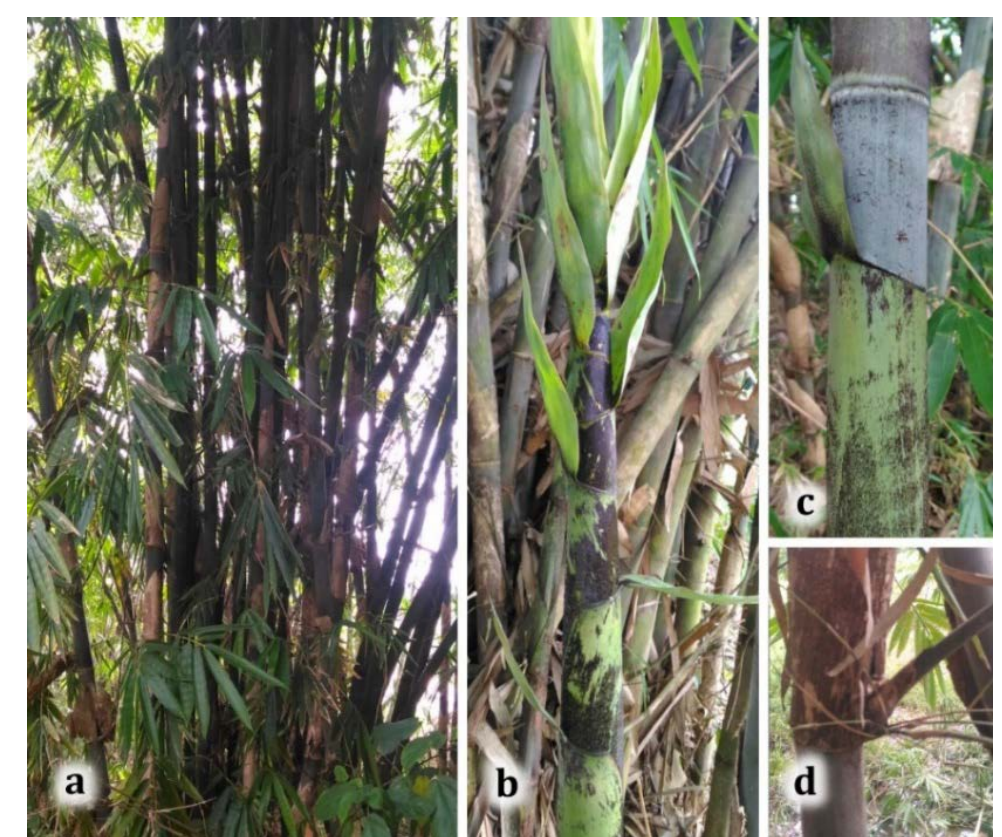

Gambar 2. Gigantochloa apus. Keterangan: perawakan (a); rebung (b); pelepah buluh saat muda (c), percabangan (d) (Foto: I Putu Gede P. Damayanto)

\section{Gigantochloa pseudoarundinacea (Gambar 3)}

Rebung berwarna hijau, tertutup miang coklat hingga hitam. Rumpun agak padat; buluh tegak dengan ujung melengkung, berwarna hijau dengan garis-garing kuning saat tua; buluh muda dilapisi miang berwarna coklat, menjadi gundul saat tua, tinggi $11-15 \mathrm{~m}$, diameter $7-8 \mathrm{~cm}$, dan ruas $42-44 \mathrm{~cm}$. Percabangan muncul jauh dari permukaan tanah, terdiri dari satu cabang yang lebih besar dikelilingi oleh beberapa cabang yang berukuran lebih kecil. Pelepah buluh mencapai $24,5 \times 53 \mathrm{~cm}$, mudah luruh, diselimuti miang berwarna coklat; kuping berbentuk bingkai, 1-2 mm, dengan bulu kejur 5-6 mm saat muda; ligula menggerigi, tinggi 1-3 mm dengan bulu kejur yang sangat halus hingga gundul; daun pelepah buluh tersebar hingga terkeluk balik, menyegitiga dengan pangkal menyempit, $12,5 \times 2,5 \mathrm{~cm}$. Daun memita, 23,2-27 × 3,2-3,4 cm; kuping kecil mencapai $1 \mathrm{~mm}$, gundul; ligula rata hingga menggerigi dengan tinggi $1-3 \mathrm{~mm}$, dengan bulu kejur halus $2 \mathrm{~mm}$ panjangnya.
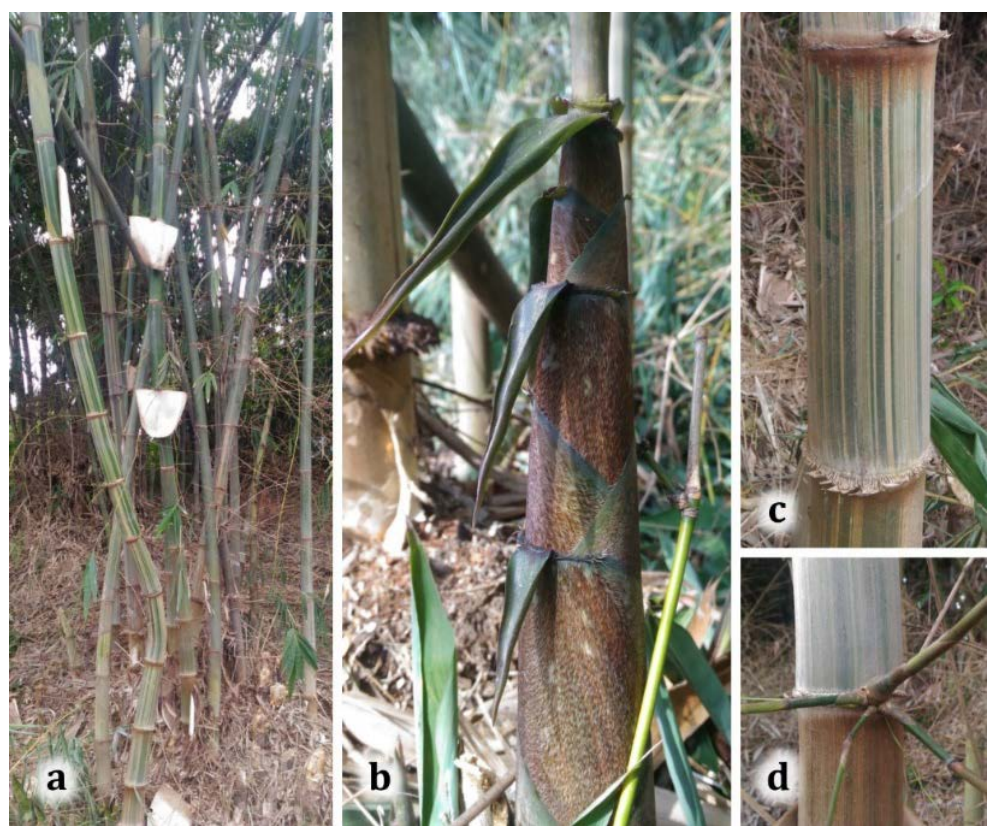

Gambar 3. Gigantochloa pseudoarundinacea. Keterangan: perawakan (a); rebung (b); buluh dengan garisgaris kekuningan (c); percabangan (d) (Foto: I Putu Gede P. Damayanto) 


\subsubsection{Kunci Identifikasi Jenis Bambu di Ecology Park}

Kunci identifikasi tumbuhan atau dikenal juga sebagai kunci determinasi tumbuhan adalah sebuah "alat bantu" untuk melakukan identifikasi suatu tumbuhan sehingga nama ilmiah tumbuhan tersebut dapat diketahui. Kunci identifikasi yang umum digunakan adalah berupa daftar ciri-ciri morfologi yang disusun secara berurutan dan bersifat dikotomi. Sifat dikotomi adalah dua karakter yang saling bertentangan, misalnya 'ada' atau 'tidak'. Pada kunci identifikasi dikotomi, terdapat dua pernyataan pada setiap satu nomor. Kedua pernyataan tersebut memunculkan karakter morfologi (bisa juga karakter lain) yang saling bertentangan. Ketika suatu karakter pada satu nomor pada kunci identifikasi telah ditentukan, maka akan ada petunjuk menuju ke nomor berikutnya sampai nama jenis tumbuhan diperoleh. Kunci identifikasi jenis bambu di Ecology Park dibuat dengan hanya menggunakan karakter vegetatif. Kunci identifikasi jenis bambu di Ecology Park disajikan dalam Tabel 2.

Tabel 2. Kunci Identifikasi Jenis Bambu di Ecology Park

1 a. Kuping pelapah buluh berbentuk membulat dengan ujung melengkung ke luar

Bambusa vulgaris

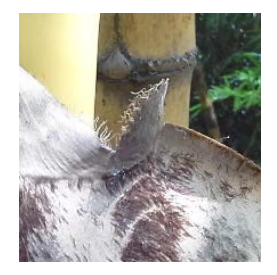

b. Kuping pelepah buluh berbentuk seperti bingkai atau seperti bingkai bergelombang

2

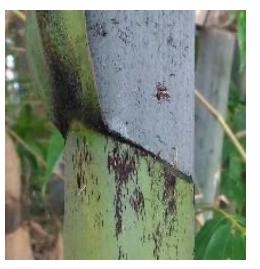

2 a. Buluh berwarna hijau tanpa garis-garis

kekuningan......

Gigantochloa apus

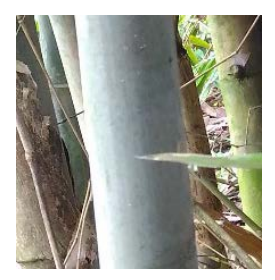

b Buluh berwarna hijau dengan garis-garis kekuningan

Gigantochloa pseudoarundinacea

\subsubsection{Peta Distribusi Jenis-jenis Bambu di Ecology Park}

Bambu B. vulgaris di Ecology Park dapat dijumpai tumbuh di pingir danau dan sungai, di pinggir jalan utama, serta sepanjang jalan setapak. Distribusi $B$. vulgaris di Indonesia dilaporkan cukup luas dan dapat dijumpai hampir di semua wilayah di Pulau Jawa (Widjaja, 2001a). Bambu G. apus di Ecology Park dapat dijumpai tumbuh di dekat jalan utama. Bambu G. apus dilaporkan ditanam di seluruh Jawa dan juga tumbuh liar di Taman Nasional Alas Purwo serta Meru Betiri (Widjaja, 2001a). Sementara itu, bambu G. pseudoarundinacea dijumpai tumbuh di dekat jalan utama di Ecology Park. Bambu ini juga dilaporkan tumbuh tersebar di seluruh Pulau Jawa (Widjaja, 2001a). Dengan demikian, ketiga jenis bambu yang ada di Ecology Park merupakan jenis-jenis bambu yang umum dijumpai di Pulau Jawa. Peta distribusi bambu di Ecology Park disajikan pada Gambar 3. 


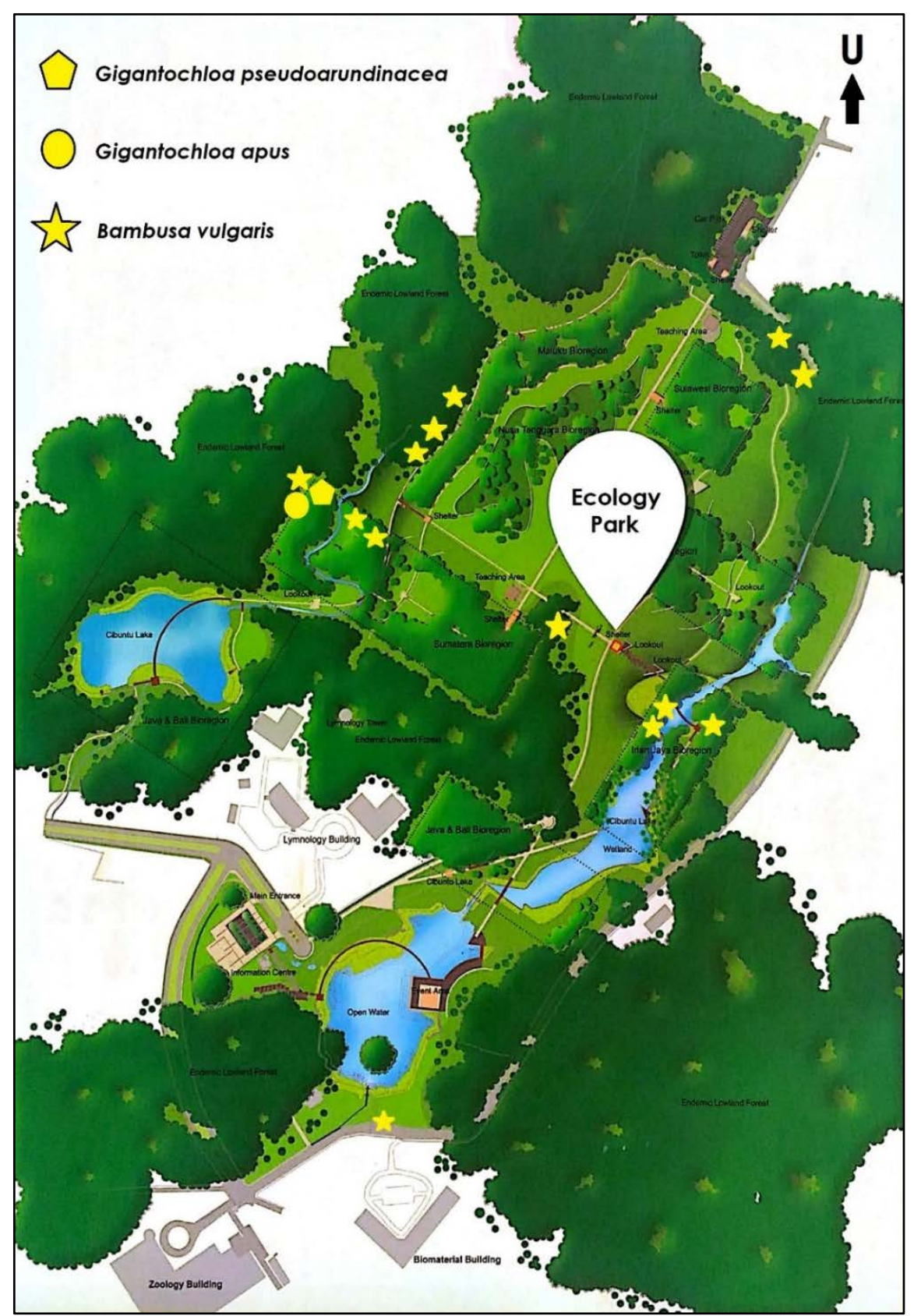

Gambar 3. Distribusi bambu di Ecology Park (Modifikasi peta kawasan Ecology Park)

\subsubsection{Rekomendasi Pengelolaan Tanaman Bambu di Ecology Park}

Ecology Park memiliki pembagian zona khusus (disebut bioregion) dalam pengelolaan koleksi tumbuhannya. Bioregion merupakan pembagian zona kawasan yang mewakili setiap kawasan hutan di Indonesia, seperti bioregion Sumatera, Jawa-Bali, Nusa Tenggara, Kalimantan, Sulawesi, Maluku, dan Papua/rian Jaya (Imron, dkk., 2016; Nafar, 2016, Madani, 2017; Sufa, 2017; Ariati, dkk., 2018). Oleh karena itu, koleksi tumbuhan, juga termasuk bambu, yang ada di dalamnya harus sesuai dengan bioregionnya. Berdasarkan peta pada Gambar 3, terlihat bahwa B. vulgaris dapat dijumpai di beberapa bioregion di Ecology Park seperti pada bioregion Maluku, Papua/lrina Jaya, Sumatera, dan sebagian kecil di luar bioregion yang ada. Damayanto, dkk. (2016) menyatakan bahwa B. vulgaris dapat dijumpai tumbuh di Papua. Beberapa spesimen $B$. vulgaris di Herbarium Bogoriense (BO) yang telah diperiksa juga menunjukan bahwa jenis bambu ini djumpai tumbuh tersebar di Sumatera dan Maluku. Widjaja (2001a) juga melaporkan bahwa distribusi $B$. vulgaris di Indonesia cukup luas, terlebih di Pulau Jawa. Dengan demikian, keberadaan jenis ini di beberapa bioregion dan di luar zona bioregion di Ecology Park sudah sesuai. Sementara itu, keberadaan jenis G. apus dan G. pseudoarundinacea di Ecology Park hanya ditemukan di bioregion Sumatera. Widjaja (1987) 
menyatakan bahwa G. pseudoarundinacea telah dibudidayakan di Sumatera. Berdasarkan pengamatan spesimen herbarium di BO, bambu G. apus dan G. pseudoarundinacea dapat djumpai tumbuh tersebar di Sumatera. Sehingga keberadaan kedua jenis bambu tersebut pada bioregion Sumatera di Ecology Park juga sudah sesuai.

Berdasarkan hal tersebut di atas, keberadaan jenis bambu B. vulgaris, G. apus, dan $G$. pseudoarundinacea pada setiap bioregion di Ecology Park diharapkan tetap dipertahankan. Meskipun demikian, keberadaan rumpun bambu di Ecology Park dapat menimbulkan potensi ancaman yang berbahaya bagi pengujung karena ditemukannya hewan liar beracun, misalnya ular, pada rumpun bambu tersebut (Nafar, 2016). Nafar (2016) juga menyatakan bahwa rumpun bambu di sepanjang tepi danau di Ecology Park dapat menghalangi potensi visual atau pemandangan ke arah danau. Selain itu, bambu memiliki zat alelopati yang dapat mengganggu bahkan menghambat pertumbuhan vegetasi lain yang berada di sekitarnya (Adkins, dkk., 2014; Sankaran, dkk., 2014; Tjitrosoedirdjo, dkk., 2016; Damayanto \& Muhaimin, 2017). Namun di sisi lain, keberadaan bambu pada suatu ekosistem juga memiliki peran ekologis yang penting, misalnya dapat mencegah erosi tanah, berperan dalam konservasi air, menyerap gas rumah kaca, dan melepaskan oksigen ke atmosfer (Wong, 2004; Wang, dkk., 2013; Huang, dkk., 2014). Sebagai contoh, bambu B. vulgaris yang tumbuh di sepanjang tepi danau di Ecology Park dapat membantu mencegah erosi tanah di sekitarnya akibat rendaman air danau saat musim hujan. Jika air danau meluap dan menggenangi bambu ini, maka tidak akan akan menyebabkan kematian pada bambu tersebut karena $B$. vulgaris mampu tumbuh pada tempat yang tergenang air selama 2-3 bulan (Widjaja, 2001a).

Nafar (2016) telah merekomendasikan agar tetap mempertahankan tanaman bambu yang ada di Ecology Park, namun sedikit mengurangi atau merapikan rumpunnya dan menghalangi sirkulasi pengunjung di sekitar rumpun bambu tersebut. Untuk merapikan rumpun bambu, dapat dilakukan dengan membuat pembatas (pagar) yang rapat setinggi kurang lebih 1 meter yang terbuat dari bilah bambu yang dianyam dan dipasang mengelilingi setiap rumpun bambu yang ada. Cara tersebut telah dilakukan di Kebun Raya Bogor dan Kebun Raya Cibodas dan terbukti bahwa rumpun bambu terlihat lebih rapi serta secara tidak langsung dapat mengurangi sirkulasi pengunjung memasuki kawasan rumpun bambu. Penjarangan bambu secara berkala juga harus dilakukan dan buluh bambu hasil penjarangan dapat dimanfaatkan kembali untuk membuat pagar atau hal lainnya. Setidaknya setiap 2 tahun sekali harus dilakukan penjarangan karena rata-rata bambu menghasilkan buluh per tahun sebanyak 5 samapi 10 buluh (Dransfield \& Widjaja, 1995).

Telah disebutkan sebelumnya bahwa keanekaragaman jenis bambu di Ecology Park tergolong sangat rendah, padahal kawasan Ecology Park masih tergolong luas dan mampu menampung penambahan koleksi tumbuhan. Untuk itu, penambahan jumlah koleksi bambu dari jenis yang lain di Ecology Park sangat disarankan terutama untuk jenis-jenis endemik dan/atau ornamental asli Indonesia. Salah satu contoh bambu ornamental Indonesia adalah S. brachycladum (bambu gading) yang memiliki buluh berwarna kuning bergaris hijau (Widjaja, dkk., 2005). Bambu tersebut terlihat sangat menarik dan dapat ditanam pada bioregion JawaBali karena jenis ini banyak dijumpai di wilayah Jawa dan Bali (Widjaja, 2001a; Widjaja, dkk., 2005). Selain itu, bambu ini juga mudah diperoleh karena diperjualbelikan sebagai tanaman hias. Sementara itu, bambu endemik sekaligus ornamental Indonesia yang dapat ditanam di bioregion Jawa adalah Dinochloa scandens (Blume ex Nees) Kuntze (bambu cangkoreh). Bambu tersebut merupakan jenis bambu liar merambat endemik Jawa Barat (Widjaja, 2001a; Damayanto, 2018b). Bambu D. scandens dapat menjadi daya tarik tersendiri di Ecology Park karena perawakannya yang tidak tegak layaknya bambu secara umum, melainkan merambat. Koleksi D. scandens di Kebun Raya Bogor dapat disapih untuk ditanam di Ecology Park.

\section{Simpulan}

Terdapat tiga jenis dari 40 rumpun bambu di Ecology Park, yaitu Bambusa vulgaris (bambu ampel), Gigantochloa apus (bambu tali), dan G. pseudoarundinacea (bambu andong). Semua jenis bambu tersebut diduga merupakan koleksi spontan Ecology Park. Terdapat dua varietas B. vulgaris di Ecology Park, yaitu $B$. vulgaris var. vulgaris dan $B$. vulgaris var. striata. Bambu $B$. vulgaris merupakan jenis yang paling mendominasi (hingga 32 rumpun) di Ecology Park. Sebagian besar bambu tersebut tumbuh di pinggir danau, tepi sungai, dan sepanjang pinggir jalan utama atau jalan setapak. Kunci identifikasi jenis dan peta distribusi bambu di Ecology Park telah berhasil disusun. Keberadaan B. vulgaris, G. apus, dan G. pseudoarundinacea pada setiap bioregion di Ecology Park diharapkan tetap dipertahankan. Bambu tersebut memiliki peran ekologis yang penting, yaitu dapat mencegah erosi tanah, berperan dalam konservasi air, menyerap gas rumah kaca, dan melepaskan oksigen ke atmosfer. Rumpun bambu di Ecology Park perlu dirapikan dengan cara dibuatkan pagar pembatas. Penjarangan rumpun bambu perlu dilakukan setidaknya setiap 2 tahun sekali. Penambahan jumlah koleksi bambu dari jenis yang lain di Ecology Park sangat disarankan terutama untuk jenis-jenis endemik dan/atau ornamental asli Indonesia, seperti Schizostachyum brachycladum (bambu gading) dan Dinochloa scandens (bambu cangkoreh). 


\section{Ucapan Terima Kasih}

Penulis mengucapkan terima kasih kepada Pusat Penelitian Biologi-LIPI dan Kepala Pusat Konservasi Tumbuhan, Kebun Raya-LIPI atas ijin yang diberikan selama penelitian di Ecology Park (Surat Izin No. B192/IPH.1/AP.01//2019). Terima kasih juga disampaikan kepada Kurator Herbarium Bogoriense (BO) atas kemudahan dalam kegiatan pemrosesan dan pengamatan spesimen. Terima kasih kepada para pihak Kebun Raya Bogor dan Pengelola Ecology Park atas kemudahan selama melakukan penelitian. Terima kasih kepada pihak pengelola atas peta kawasan Ecology Park yang disediakan dan kepada Peneliti Kebun Raya BogorLIPI, Peniwidiyanti, S. Hut. atas bantuannya dalam mencari daftar jenis tumbuhan Ecology Park. Terima kasih juga disampaikan kepada Dr. Siti Roosita Ariati, Peneliti Kebun Raya Bogor-LIPI, atas diskusi yang sangat berharga terkait daftar jenis tumbuhan di Ecology Park dan Bapak Sumadi, salah satu staf pengelola Ecology Park, atas informasi yang diberikan. Tulisan ini merupakan hasil kegiatan magang penulis, Sri Mulyani, di BO.

\section{Daftar Pustaka}

Adkins, S., S. Shrestha, A. Shabbir \& B. B. Shrestha. 2014. The biology and management of parthenium weed: an invasive weed now affecting the native and agro-ecosystems of Nepal. Proceedings of the International Conference on Invasive Alien Species Management: 23-29.

Ariati, S. R., R. S. Astuti \& Ruspandi (editor). 2018. An alphabetical list of plant species cultivated in the Ecopark Cibinong Science Center and Botanic Gardens. Center for Plant Conservation Botanic Gardens, LIPI, Bogor.

Astuti, D. \& H. Kurniati. 2010. Keragaman genetik amfibia kodok (Rana nicobariensis) di Ecology Park, Cibinong berdasarkan sekuen DNA dari mitokondria d-loop. Jurnal Biologi Indonesia 6(3): 405-414.

Boerdeaux, C. Z. 2015. Keanekaragaman lumut kerak sebagai bioindikator kualitas udara di Kebun Raya Cibodas, Kebun Raya Bogor dan Ecopark-LIPI Cibinong. S.Hut. Skripsi (Unpublished) Departemen Konservasi Sumberdaya Hutan dan Ekowisata, Fakultas Kehutanan, Institut Pertanian Bogor.

Damayanto, I P. G. P. 2018a. Koleksi bambu Taman Eden 100, Kabupaten Toba Samosir, Sumatera Utara dan perannya dalam taman. Jurnal Arsitektur Lansekap 4(2): 210-218.

Damayanto, I P. G. P. 2018b. Dinochloa malayana S.Dransf. (Poaceae: Bambusoideae), a new record for Indonesia. Reinwardtia 17(1): 35-37.

Damayanto, I P. G. P. \& E. A. Widjaja. 2016. A new species of Schizostachyum (Poaceae: Bambusoideae) from Sumba Island, Indonesia. Reinwardtia 15(2): 119-122.

Damayanto, I P. G. P. \& E. A. Widjaja. 2017. A noteworthy Dendrocalamus (Poaceae: Bambusoideae) from Sumatra, Indonesia. The Gardens' Bulletin Singapore 69(1): 75-80.

Damayanto, I P. G. P. \& M. Muhaimin. 2017. Notes on Chimonobambusa quadrangularis (Franceschi) Makino (Poaceae: Bambusoideae) as an invasive alien plant species in Indonesia. Floribunda 5(7): 253-257.

Damayanto, I P. G. P., Y. M. Mambrasar \& P. Hutabarat. 2016. Bamboos (Poaceae: Bambusoideae) of Papua, Indonesia. Jurnal Biologi Papua 8(2): 57-61.

Djarwaningsih, T., S. Sunarti \& K. Kramadibrata (editor). 2002. Panduan pengolahan dan pengelolaan material herbarium serta pegendalian hama terpadu di Herbarium Bogoriense. Herbarium Bogoriense, Bidang Botani, Pusat Penelitian Biologi - LIPI, Bogor.

Dransfield, S. \& E. A. Widjaja (editor). 1995. Plant resousces of South-East Asia, no 7. bamboos. Backhuys Publishers, Leiden.

Ervianti, D. 2015. Keanekaragaman dan sebaran spasial jenis bambu di Sulawesi. S.Si. Skripsi (Unpublished) Program Studi Biologi, Fakultas MIPA, Universitas Negeri Jakarta.

Hidayati, N, M. Mansur \& T. Juhaeti. 2013. Variasi serapan karbondioksida $\left(\mathrm{CO}_{2}\right)$ Jenis-jenis pohon di "Ecopark" Cibinong dan kaitannya dengan potensi mitigasi gas rumah kaca. Buletin Kebun Raya 16(1): 38-50.

Huang, Z. T., Y. F. Li, P. K. Jiang, S. X. Chang, Z. L. Song, J. Liu \& G. M. Zhou. 2014. Long term intensive management increased carbon occluded in phytolith (PhytOC) in bamboo forest soil. Scientific Reports 4(3602): 1-5.

Imron, H. M. B., A. Chodiq \& Amas. 2016. Mengenal lebih dekat Cibinong Science Bogor - Botanical Garden (CSC-BG) Lembaga IImu Pengetahuan Indonesia. LIPI, Bogor.

Jannah, H. N. 2017. Ecology Park, danau dora. Available online at: http://www.depokpos.com/arsip/2017/08/ecology-park-danau-dora/ (diakses pada 16 Februari 2019).

Janzen, D. H. 1976. Why bamboos wait so long to flower? Annual Review of Ecology and Systematics 7(1): 347-391.

Kintamani, E., Yulizah, \& J. S. Rahajoe. 2017. Input hara dari nekromasa pada ekosistem buatan Sumatera dan Jawa di Ecopark, Cibinong Science Center. Prosiding Semnas BIOETI Ke-4 dan Kongres PTTI Ke-12: 161-169. 
Kurniati, H. 2010. Keragaman dan kelimpahan jenis kodok serta hubungannya dengan vegetasi pada lahan basah "Ecology Park", Kampus LIPI Cibinong. Berita Biologi 10(3): 283-296.

Liberani, C. 2017. Banyak belum tahu, ini sejarah berdirinya Tugu Digulis, ceritanya bikin haru. Available online at: $\quad$ http://pontianak.tribunnews.com/2017/10/24/banyak-belum-tahu-ini-sejarah-berdirinya-tugudigulis-ceritanya-bikin-haru (diakses pada 1 Februari 2019).

Madani, M. A. 2017. In Picture: KLHK Tanam 250 Pohon Endemik di Kawasan Ecopark Cibinong. Available online at: https://www.republika.co.id/berita/nasional/umum/17/03/29/onkwp0283-klhk-tanam-250pohon-endemik-di-kawasan-ecopark-cibinong (diakses pada 10 Januari 2019).

McClure, F. A. 1945. Suggestions on how to collect bamboos. Division of Latin American Agriculture, Office of Foreign Agricultural Relations, Washington DC.

Nafar, S. 2016. Desain ekologis taman koleksi pakis berbasis sistem klasifikasi bioregion di Ecopark, Cibinong Science Center-Botanic Gardens. S.P. Skripsi (Unpublished) Departemen Arsitektur Lanskap, Fakultas Pertanian, Institut Pertanian Bogor.

Nafar, S. \& A. Gunawan. 2017. Ecological design of fernery based on bioregion classification system in Ecopark Cibinong Science Center Botanic Gardens, Indonesia. IOP Conference Series: Earth and Environmental Science 91: 1-7.

Noviady, I. \& R. R. Rivai. 2015. Identifikasi kondisi kesehatan pohon peneduh di kawasan Ecopark, Cibinong Science Center-Botanic Gardens. Prosiding Seminar Nasional Masyarakat Biodiversitas Indonesia 1(6): 1385-1391.

Putri, E. K. \& T. Chikmawati. 2015. Leaf flushing as taxonomy evidence of some Diospyros species. Floribunda 5(2): 31-47.

Rochim, F. N. \& J. A. Syahbana. 2013. Penetapan fungsi dan kesesuaian vegetasi pada taman publik sebagai ruang terbuka hijau (RTH) di Kota Pekalongan (studi kasus: Taman Monumen 45 Kota Pekalongan). Jurnal Teknik PWK 2(3): 314-327.

Rugayah, E. A. Widjaja \& Praptiwi (editor). 2004. Pedoman pengumpulan data keanekaragaman flora. Pusat Penelitian Biologi - LIPI, Bogor.

Sankaran, K. V., T. V. Sajeev \& T. A. Suresh. 2014. Invasive plants threats to forests in the humid tropics: a case study from Kerala State, India. Proceedings of the International Conference on Invasive Alien Species Management: 7-17.

Sufa, T. 2017. Ecopark vital conservation area for Bogor residents. Available online at: http://www.thejakartapost.com/news/2017/11/20/ecopark-vital-conservation-area-for-bogorresidents.html (diakses pada 9 Januari 2019).

Tauhid. 2018. Senjata tradisional simbol perjuangan di Monumen Bambu Runcing. Available online at: https://www.indonesiakaya.com/jelajah-indonesia/detail/senjata-tradisional-simbol-perjuangan-dimonumen-bambu-runcing (diakses pada 10 Februari 2019).

Tjitrosoedirdjo, S. S., I. Mawardi \& S. Tjitrosoedirdjo. 2016. 75 important invasive plant species in Indonesia. Seameo Biotrop, Bogor.

Vorontsova, M. S., L. G. Clark, J. Dransfield, R. H. A. Govaerts \& W. J. Baker. 2016. World checklist of bamboos and rattans. Inbar Technical Report 37: 1-454.

Wang, B, W. J. Wei, C. J. Liu, W. Z. You, X. Niu \& R. Z. Man. 2013. Biomass and carbon stock in moso bamboo forest in subtropical China: characteristics and implications. Journal Tropical Forest Science 25(1): 137-148.

Widjaja, E. A. 1987. A revision of Malesian Gigantochloa (Poaceae - Bambusoideae). Reinwardtia 10(3): 291-380.

Widjaja, E. A. 1997. New taxa in Indonesian bamboos. Reinwardtia 11(2): 57-152.

Widjaja, E.A. 2001a. Identikit jenis-jenis bambu di Jawa. Pusat Penelitian dan Pengembangan Biologi - LIPI, Bogor.

Widjaja, E. A. 2001b. Identikit jenis-jenis bambu di Kepulauan Sunda Kecil. Pusat Penelitian dan Pengembangan Biologi - LIPI, Bogor.

Widjaja, E. A., I. P. Astuti, I. B. K. Arinasa \& I W. Sumantera. 2005. Identikit bambu di Bali. Bidang Botani, Pusat Penelitian Biologi - LIPI, Bogor.

Widodo, W. \& E. Sulystiadi. 2016. Pola distribusi dan dinamika komunitas burung di kawasan "Cibinong Science Center". Jurnal Biologi Indonesia 12(1): 145-158.

Wong K. M. 2004. Bamboo: the amazing grass, a guide to diversity and study of bamboos in Southeast Asia. IPGRI and University of Malaya, Malaysia. 